\title{
The thermal stress of roller-compacted concrete dams during construction
}

\author{
Nikolay Aniskin ${ }^{1}$, and Chuc Nguyen Trong ${ }^{1, *}$ \\ ${ }^{1}$ Moscow State University of Civil Engineering, Yaroslavskoe shosse, 26, Moscow, 129337, Russia
}

\begin{abstract}
During the construction of concrete dams from rolledcompacted concrete, the main effect on the structure are the temperature effects. As a result of heat generation during hydration of cement and the influence of many other factors, significant temperature gradients and cracks may occur. In this paper, the optimal maximum temperatures arising in the body of the concrete dam under construction are determined by the method of experiment planning and the method of numerical simulation the finite element method. The analysis of the influence of the acting factors on the temperature regime and the thermal stressed state at the rock-built concrete dam from rolled concrete is carried out. The dependences are obtained and nomograms are constructed to determine the optimal parameters. With the help of the computer program Midas Civil 2011, calculations of the temperature regime of the constructed dam were carried out and the maximum temperatures were determined. The calculations of thermal stress state of the structure along with an analysis of the possible cracking are conducted.
\end{abstract}

\section{Introduction}

Mass concrete structures are often constructed in hydraulic engineering. First of all, these are massive concrete dams, which include gravity and massive-buttress dams. They are widely used in modern hydraulic engineering construction [1-2]. One of the significant impacts on such structures is the temperature effect, which causes a change in the stressstrain state of the structure both in the construction and operational periods [3-4].

The temperature regime of the concrete array of the dam during its construction is formed under the influence of many factors. It is possible to distinguish external temperature influences: air temperature, temperature of the basis, influence of insolation, existence of wind and its direction. The main factor acting during the construction period is exothermic cement. The amount of exothermic heating affects the composition of the concrete mixture: cement consumption and heat dissipation.

In addition, the formation of the temperature field is influenced by many technological factors: the scheme of concreting, the temperature of the stacked concrete, the thickness of the stacked concrete layers, the intensity of concreting, the use of artificial cooling of the concrete array, etc. In the process of construction of the array and intensive heat dissipation of cement, there is a significant heating of the inner zone of the array. As a result, there

* Corresponding author: ntchuc.mta198@gmail.com 
might be great temperature differences that cause significant tensile stresses and lead to crackings [5 - 6].

The object of this article is a dam with a height of $45 \mathrm{~m}$. This dam was built in the summer in the North of Viet Nam. The climate of this region is characterized by fluctuations in air temperature from $15^{\circ} \mathrm{C}$ in winter to $26.5^{\circ} \mathrm{C}$ in summer (Figure 1) [7].

$\mathrm{y}=7 \mathrm{E}-09 \mathrm{x}^{4}-6 \mathrm{E}-06 \mathrm{x}^{3}+0.0012 \mathrm{x}^{2}-0.0114 \mathrm{x}+14.858$

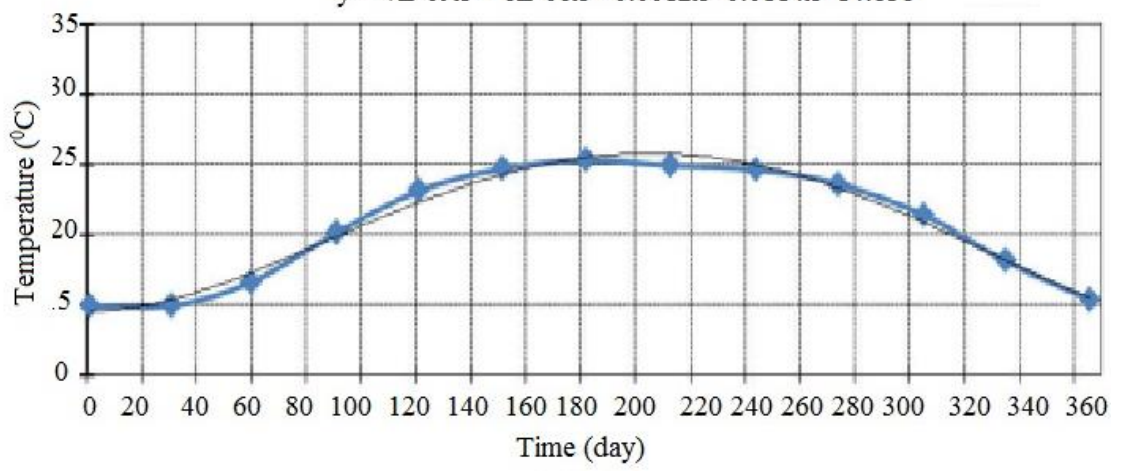

Fig. 1. Fluctuations in temperature during the year in Northern Vietnam

Average monthly intensity of concreting $\mathrm{V}=0.3 \mathrm{~m} /$ day. In calculations, the following thermo-physical characteristics of the roller-compacted concrete (RCC) and the dam base are table 1 and the calculation model is shown in Figure 2.

Table 1. Thermal and structural properties of RCC and foundation of the dam

\begin{tabular}{|c|l|c|c|}
\hline No & \multicolumn{1}{|c|}{ Material } & RCC & Foundation \\
\hline 1 & Heat conduction coefficient. $\mathrm{W} /\left(\mathrm{m} .{ }^{0} \mathrm{C}\right)$ & 2.0 & 2.0 \\
\hline 2 & Specific heat, $\mathrm{kJ} /\left(\mathrm{kg} .{ }^{0} \mathrm{C}\right)$ & 0.945 & 0.850 \\
\hline 3 & Density, $\mathrm{kg} / \mathrm{m}^{3}$ & 2450 & 2650 \\
\hline 4 & $\begin{array}{l}\text { Heat transfer coefficient from the exposed concrete-air } \\
\text { surface, } \mathrm{W} / \mathrm{m}^{2}{ }^{0} \mathrm{C}\end{array}$ & 14.50 & 14.00 \\
\hline 5 & Elastic modulus $\left(\mathrm{N} / \mathrm{m}^{2}\right)$ & $2.50 \times 10^{10}$ & $1.8 \times 10^{10}$ \\
\hline 6 & Thermal expansion Coefficient $\left(1 /{ }^{0} \mathrm{C}\right)$ & $1.0 \times 10^{-5}$ & $1.0 \times 10^{-5}$ \\
\hline 7 & Poisson's ratio & 0.20 & 0.20 \\
\hline
\end{tabular}

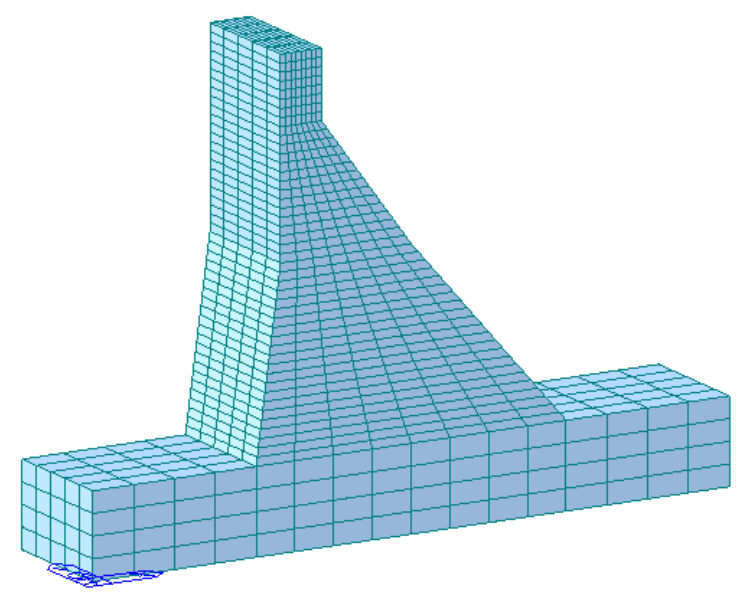

Fig. 2. Calculating model of roller-compacted concrete 


\section{Materials and methods}

The formation of the temperature regime of the constructed concrete dam is influenced by a large number of factors - climatic and technological. In this paper, a method of experiment planning is used to build a mathematical model [8].

In calculation of the main factors affecting the temperature regime:

- $\mathrm{X}_{1}$ (Ц) - cement consumption $\left(\mathrm{kg} / \mathrm{m}^{3}\right.$ ) (accepted the border changes from 50 to 200 for rolled compacted concrete);

- $\mathrm{X}_{2}(\Delta)$ - thickness of the stacked layer $(\mathrm{m})$ (accepted the border change from 0.3 to 1.5 for the rolled compacted concrete);

- $\mathrm{X}_{3}\left(\ni_{\max }\right)$ - cement maximum heat released $(\mathrm{kJ} / \mathrm{kg})$ (accepted border change from 120 to 350 for the rolled compacted concrete;

- $\mathrm{X}_{4}\left(\mathrm{t}_{\mathrm{pl}}\right)$ - temperature of the stacked concrete $\left({ }^{0} \mathrm{C}\right)$ (accepted border change for both options of placement from 10 to 22).

Simulation mathematical models of maximum temperature were searched in the form of polynomials of the second degree from the accepted factors [9]:

$Y_{i}=b_{o}+b_{1} X_{1}+b_{2} X_{2}+b_{3} X_{3}+b_{4} X_{4}+b_{12} X_{1} X_{2}+b_{13} X_{1} X_{3}+b_{14} X_{1} X_{4}+b_{23} X_{2} X_{3}+b_{24} X_{2} X_{4}+$ $b_{34} X_{3} X_{4}+b_{1234} X_{1} X_{2} X_{3} X_{4}$

A plan for a full-factor experiment was drawn up, including 16 calculations with all possible variations of factors at their minimum and maximum values. To check the adequacy of the obtained solution, another experiment was carried out with zero levels of factors (equal to the average values of factors between their minimal and maximal values).

The solution of the temperature problem is based on the solution of the basic differential equation of the heat conduction theory [10]:

$$
\frac{\partial}{\partial x}\left(k_{x} \frac{\partial t}{\partial x}\right)+\frac{\partial}{\partial y}\left(k_{y} \frac{\partial t}{\partial y}\right)+\frac{\partial}{\partial z}\left(k_{z} \frac{\partial t}{\partial z}\right)+q_{v}=\rho c \frac{\partial t}{\partial \tau},
$$

where: $\mathrm{t}$-Temperature, $\left({ }^{0} \mathrm{C}\right)$ at time " $\tau$ ", (day) and " $\mathrm{x}, \mathrm{y}, \mathrm{z}$ " coordinates;

$\mathrm{k}_{\mathrm{x}}, \mathrm{k}_{\mathrm{y}}, \mathrm{k}_{\mathrm{z}}$ - the coefficient of thermal conductivity of the material in the direction of the coordinate axes ox, oy, oz, $\left(\mathrm{k}_{\mathrm{x}}=\mathrm{k}_{\mathrm{y}}=\mathrm{k}_{\mathrm{z}}=\lambda / \mathrm{c} . \rho\right), \mathrm{m}^{2} / \mathrm{s}$;

$\lambda$ - thermal conductivity of the material, $\mathrm{W} / \mathrm{m}^{0} \mathrm{C}$;

$\mathrm{q}_{\mathrm{v}}$ - the amount of heat generated by internal sources at a given time, for example, during the cement hydration process, $\mathrm{kcal} / \mathrm{m}^{3}$;

$\mathrm{c}$ - specific heat coefficient, $\mathrm{kJ} / \mathrm{kg} .{ }^{0} \mathrm{C}$;

$\rho$ - density of concrete, $\mathrm{kg} / \mathrm{m}^{3}$.

According to [11], the concrete heat released at the instant time $\tau$ was determined by the formula (3):

$$
Q_{\ni}(\tau)=Q_{\text {макс }}\left[1-\left(1+A_{20} \tau\right)^{-n}\right]
$$

where: $\mathrm{Q}_{\text {макс }}=\mathrm{q}_{\mathrm{T}} Ц$ - full heat emission of cement (at the end of hydration), $\mathrm{kJ} / \mathrm{m}^{3}$;

Ц - amount of cement per unit volume, $\mathrm{kg} / \mathrm{m}^{3}$;

$\mathrm{A}_{20}$ - coefficient of heat dissipation speed related to the hardening temperature of $\mathrm{t}$ $=20^{0} \mathrm{C}, \mathrm{A}_{20}=0.012-0.015 \mathrm{~h}^{-1}$;

$\mathrm{n}$ - constant, depending on the concrete mixture casting temperature, according to the study $n=0.83$ [12].

\section{Research results}

For all experiments of the plan, the calculations of the temperature regime of the concrete dam under construction by the finite element method using the software package Midas civil 2011 were conducted [13]. The matrix of experiment planning and levels of factors 
and maximum temperatures in the dam depending on the conditions of construction are shown in the table. 2.

Table 2. Planning matrix experiments

\begin{tabular}{|c|c|c|c|c|c|c|c|c|c|}
\hline \multirow{2}{*}{ No } & \multirow[b]{2}{*}{$\mathbf{x}_{1}$} & \multirow{2}{*}{$\mathbf{x}_{2}$} & \multirow{2}{*}{$\mathbf{x}_{3}$} & \multirow{2}{*}{$\mathbf{x}_{4}$} & \multicolumn{4}{|c|}{ Values of factors in the natural scale } & \multirow{2}{*}{$\mathrm{T}_{\max },{ }^{0} \mathrm{C}$} \\
\hline & & & & & $\mathrm{X}_{1}, \mathrm{~kg} / \mathrm{m}^{3}$ & $X_{2}, m$ & $\mathrm{X}_{3}, \mathrm{~kJ} / \mathrm{kg}$ & $\mathrm{X}_{4},{ }^{0} \mathrm{C}$ & \\
\hline 1 & -1 & -1 & -1 & -1 & 50 & 0.3 & 120 & 10 & 31.46 \\
\hline 2 & 1 & -1 & -1 & -1 & 200 & 0.3 & 120 & 10 & 36.37 \\
\hline 3 & -1 & 1 & -1 & -1 & 50 & 1.5 & 120 & 10 & 33.50 \\
\hline 4 & 1 & 1 & -1 & -1 & 200 & 1.5 & 120 & 10 & 38.80 \\
\hline 5 & -1 & -1 & 1 & -1 & 50 & 0.3 & 350 & 10 & 34.60 \\
\hline 6 & 1 & -1 & 1 & -1 & 200 & 0.3 & 350 & 10 & 48.94 \\
\hline 7 & -1 & 1 & 1 & -1 & 50 & 1.5 & 350 & 10 & 36.89 \\
\hline 8 & 1 & 1 & 1 & -1 & 200 & 1.5 & 350 & 10 & 52.39 \\
\hline 9 & -1 & -1 & -1 & 1 & 50 & 0.3 & 120 & 25 & 32.30 \\
\hline 10 & 1 & -1 & -1 & 1 & 200 & 0.3 & 120 & 25 & 37.19 \\
\hline 11 & -1 & 1 & -1 & 1 & 50 & 1.5 & 120 & 25 & 34.48 \\
\hline 12 & 1 & 1 & -1 & 1 & 200 & 1.5 & 120 & 25 & 39.83 \\
\hline 13 & -1 & -1 & 1 & 1 & 50 & 0.3 & 350 & 25 & 35.42 \\
\hline 14 & 1 & -1 & 1 & 1 & 200 & 0.3 & 350 & 25 & 49.77 \\
\hline 15 & -1 & 1 & 1 & 1 & 50 & 1.5 & 350 & 25 & 37.89 \\
\hline 16 & 1 & 1 & 1 & 1 & 200 & 1.5 & 350 & 25 & 53.52 \\
\hline 17 & 0 & 0 & 0 & 0 & 125 & 0.9 & 235 & 17,5 & 39.68 \\
\hline
\end{tabular}

Simulation mathematical models of maximum temperatures, obtained through the results of calculations of the temperature regime, have the form :

$$
\begin{aligned}
T_{\max }=39.58+5.02 X_{1}+ & 1.33 X_{2}+4.09 X_{3}+0.47 X_{4}+0.21 X_{1} X_{2}+2.46 X_{1} X_{3}+ \\
& +0.01 X_{1} X_{4}+0.17 X_{2} X_{3}+0.05 X_{2} X_{4}+0.01 X_{3} X_{4}
\end{aligned}
$$

After consideration of the functions of responses (equation 4), it is possible to point out the followings: all the above factors have a fairly large impact on the value of the maximum temperature of the concrete dam. The temperature is most dependent on the factors $\mathrm{X}_{1}(Ц)$ and $X_{3}\left(\ni_{\max }\right)$. These two factors directly and through the members of equation (4) with regard to their interaction $\left(\mathrm{X}_{1}, \mathrm{X}_{3}\right)$ have the greatest impact on the value of maximum temperature in a concrete dam. Another significant factor is the thickness of the stacked layer $\left(\mathrm{X}_{2}\right)$, the increase of which leads to an increase in the exothermal heating of the concrete dam. The factor $\mathrm{X}_{4}$ (the temperature of the concrete mix to be laid) practically does not influence the value of the maximum temperature.

As a result of the analysis of the influence of two pairwise chosen factors (with the other factors taken into account) $\left(\mathrm{X}_{1}, \mathrm{X}_{2}\right),\left(\mathrm{X}_{1}, \mathrm{X}_{3}\right),\left(\mathrm{X}_{1}, \mathrm{X}_{4}\right),\left(\mathrm{X}_{2}, \mathrm{X}_{3}\right),\left(\mathrm{X}_{2}, \mathrm{X}_{4}\right),\left(\mathrm{X}_{3}, \mathrm{X}_{4}\right)$ from equation (4), simpler equations of influence of 2 factors on the temperature regime in the dam of roller-compacted concrete dam is given in Table 3.

With the help of the computer program Matlab, nomograms were obtained to determine the maximum temperature in accordance with the simplified equations from Table 3 . The nomograms, from which can quickly estimate the temperature regime of a concrete gravity dam, are shown in Figure 3 (a-e). 
Table 3. Factors affecting the temperature field in the dam

\begin{tabular}{|c|c|c|}
\hline No & Factors & Functions \\
\hline 1 & when $\mathrm{X}_{3}=0, \mathrm{X}_{4}=0,-1 \leq \mathrm{X}_{1} \leq 1 ;-1 \leq \mathrm{X}_{2} \leq 1$ & $\mathrm{~T}_{\max }=39,58+5.02 \mathrm{X}_{1}+1.33 \mathrm{X}_{2}+0.21 \mathrm{X}_{1} \mathrm{X}_{2}$ \\
\hline 2 & when $\mathrm{X}_{2}=0, \mathrm{X}_{4}=0,-1 \leq \mathrm{X}_{1} \leq 1 ;-1 \leq \mathrm{X}_{3} \leq 1$ & $\mathrm{~T}_{\max }=39.58+5.02 \mathrm{X}_{1}+4.09 \mathrm{X}_{3}+2.46 \mathrm{X}_{1} \mathrm{X}_{3}$ \\
\hline 3 & when $\mathrm{X}_{2}=0, \mathrm{X}_{3}=0,-1 \leq \mathrm{X}_{1} \leq 1 ;-1 \leq \mathrm{X}_{4} \leq 1$ & $\mathrm{~T}_{\max }=39.58+5.02 \mathrm{X}_{1}+0.47 \mathrm{X}_{4}+0.01 \mathrm{X}_{1} \mathrm{X}_{4}$ \\
\hline 4 & when $\mathrm{X}_{1}=0, \mathrm{X}_{4}=0,-1 \leq \mathrm{X}_{2} \leq 1 ;-1 \leq \mathrm{X}_{3} \leq 1$ & $\mathrm{~T}_{\max }=39.58+1.33 \mathrm{X}_{2}+4.09 \mathrm{X}_{3}+0.17 \mathrm{X}_{2} \mathrm{X}_{3}$ \\
\hline 5 & when $\mathrm{X}_{1}=0, \mathrm{X}_{3}=0,-1 \leq \mathrm{X}_{2} \leq 1 ;-1 \leq \mathrm{X}_{4} \leq 1$ & $\mathrm{~T}_{\max }=39.58+1.33 \mathrm{X}_{2}+0.47 \mathrm{X}_{4}+0.05 \mathrm{X}_{2} \mathrm{X}_{4}$ \\
\hline 6 & when $\mathrm{X}_{1}=0, \mathrm{X}_{2}=0,-1 \leq \mathrm{X}_{3} \leq 1 ;-1 \leq \mathrm{X}_{4} \leq 1$ & $\mathrm{~T}_{\max }=39.58+4.09 \mathrm{X}_{3}+0.47 \mathrm{X}_{4}+0.01 \mathrm{X}_{3} \mathrm{X}_{4}$ \\
\hline
\end{tabular}

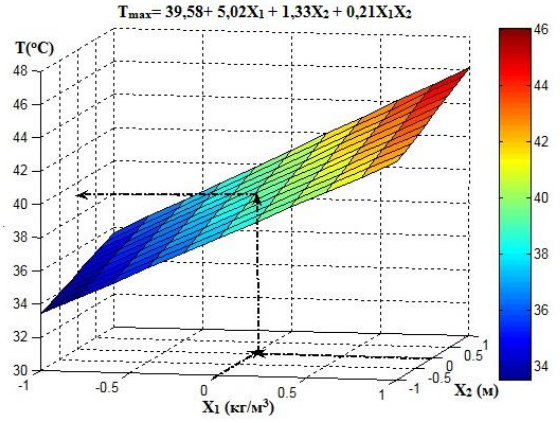

$\mathrm{a}$ - when $\ni_{\max }=235 \mathrm{~kJ} / \mathrm{kg}, \mathrm{t}_{\mathrm{pl}}=17.5^{\circ} \mathrm{C}$, $X_{1}\left(\right.$ Ц) $=(50-200) \mathrm{kg} / \mathrm{m}^{3}, X_{2}(\Delta)=(0.3-1.5) \mathrm{m}$

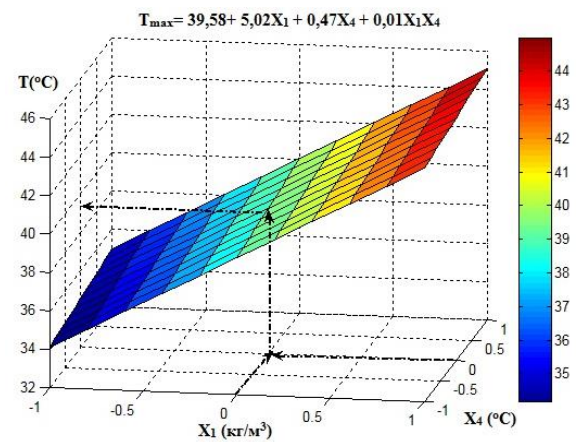

$\mathrm{c}$ - when $\Delta=0.9 \mathrm{~m}, \ni_{\max }=235 \mathrm{~kJ} / \mathrm{kg}, \mathrm{X}_{1}(Ц)=(50$ 200) $\mathrm{kg} / \mathrm{m}^{3}, \mathrm{X}_{4}\left(\mathrm{t}_{\mathrm{pl}}\right)=(10-25)^{\circ} \mathrm{C}$

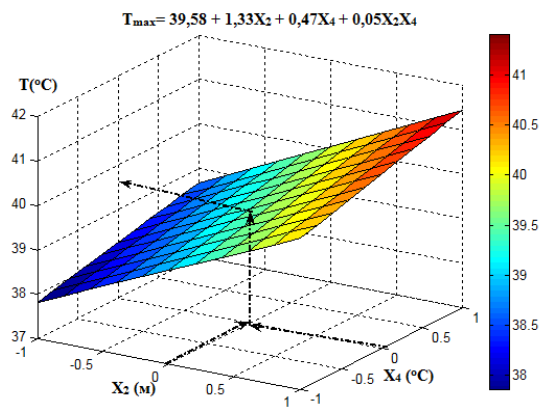

e - when $Ц=125 \mathrm{~kg} / \mathrm{m}^{3}, \ni_{\max }=235 \mathrm{~kJ} / \mathrm{kg}$, $\mathrm{X}_{2}(\Delta)=(0.3-1.5) \mathrm{m}, \mathrm{X}_{4}\left(\mathrm{t}_{\mathrm{pl}}\right)=(10-25)^{0} \mathrm{C}$

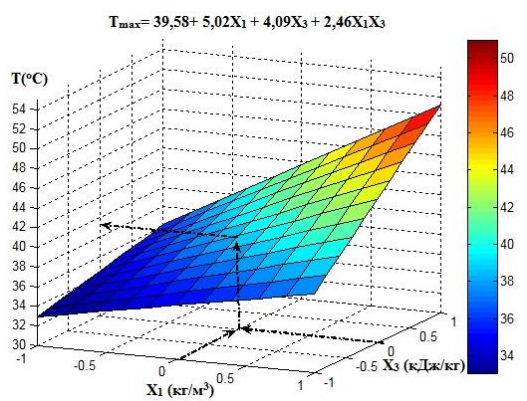

$\mathrm{b}$ - when $\Delta=0.9 \mathrm{~m}, \mathrm{t}_{\mathrm{pl}}=17.5^{\circ} \mathrm{C}, \mathrm{X}_{1}(Ц)=$ $(50-200) \mathrm{kg} / \mathrm{m}^{3}, X_{3}(Э)=(120-350) \mathrm{kJ} / \mathrm{kg}$

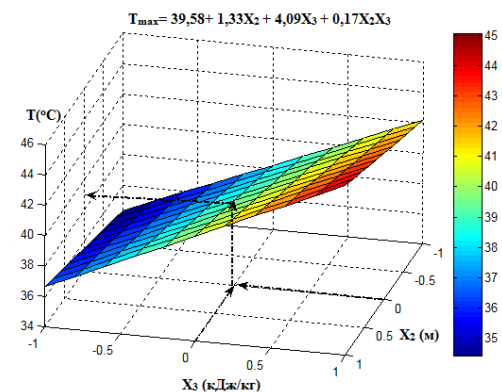

$\mathrm{d}$ - when $Ц=125 \mathrm{~kg} / \mathrm{m}^{3}, \mathrm{t}_{\mathrm{pl}}=17.5^{\circ} \mathrm{C}$, $\mathrm{X}_{2}(\Delta)=(0.3-1.5) \mathrm{m}, \mathrm{X}_{3}(\ni)=(120-350)$ $\mathrm{kJ} / \mathrm{kg}$

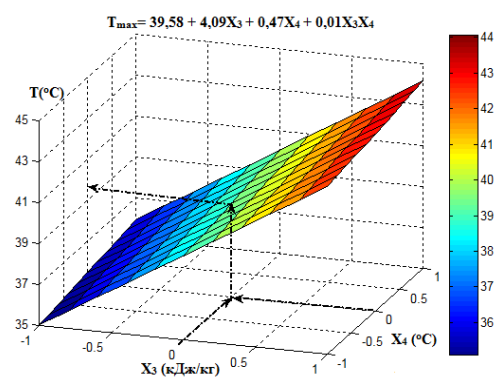

$\mathrm{f}$ - when $Ц=125 \mathrm{~kg} / \mathrm{m}^{3}, \Delta=0.9 \mathrm{~m}, \mathrm{X}_{3}(Э)=$ $(120-350) \mathrm{kJ} / \mathrm{kg}, \mathrm{X}_{4}\left(\mathrm{t}_{\mathrm{p}}\right)=(10-25)^{0} \mathrm{C}$

Fig. 3. Nomograms to determine the maximum temperature in the dam 
Cases with these factors were considered: cement consumption $Ц=125 \mathrm{~kg} / \mathrm{m}^{3}$, thickness of the lift placed $\Delta=1.5 \mathrm{~m}$, cement maximum heat release $\Im_{\max }=235 \mathrm{~kJ} / \mathrm{kg}$, temperature of concrete placed $t_{p l}=25^{0} \mathrm{C}$. Computer program Midas Civil 2011 were used to determine maximum temperature of roller-compacted concrete dam during the process of construction $\mathbf{T}_{\max }=38.99^{\circ} \mathbf{C}$. The temperature field of the dam at 3600 hours after the beginning of construction is shown in Figure 4.

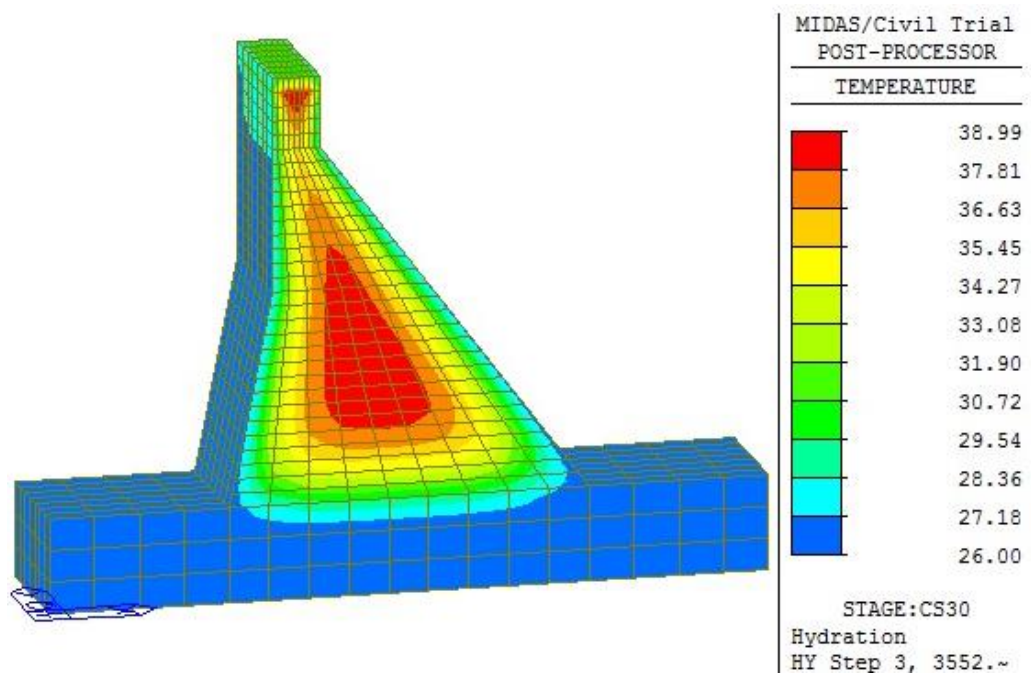

Fig. 4. The temperature field of the dam at 3600 hours from the beginning to build (Ц $=125 \mathrm{~kg} / \mathrm{m}^{3}, \Delta$ $=1.5 \mathrm{~m}, \ni_{\max }=235 \mathrm{~kJ} / \mathrm{kg}, \mathrm{t}_{\mathrm{pl}}=25^{\circ} \mathrm{C}$ )

Figure 3e. shows the maximum temperature of roller-compacted concrete dam during the process of construction $\mathrm{T}_{\max }=39.58^{\circ} \mathrm{C}$. The error in the result obtained from the nomogram in Figure 3e compared with the result obtained under the Midas Civil 2011 program is $5.5 \%$, which can be accepted as a satisfactory value.

According to construction practice of mass concrete dams depending on «pinching» conditions and block location in the dam body, the emergence of temperature cracks is connected with temperature differences. Analysis of temperature field and the thermally stressed state in 4 nodes (No 960, 966, 925 and 51) are shown in Figure 5. The results of their analysis, temperature field and thermal stressed state are shown in Figures 6-8.

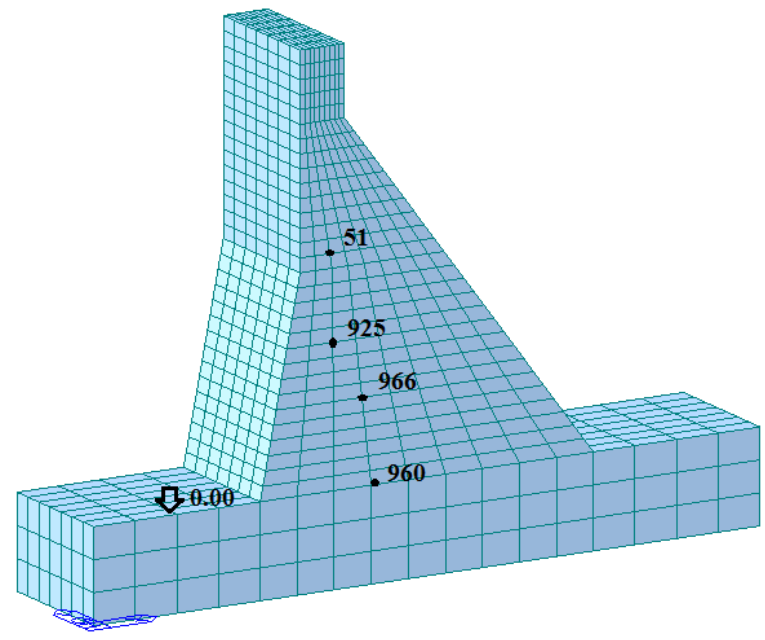

Fig. 5. Analysis of temperature field and the thermal stressed state in 4 nodes (960, 966, 925 and 51) 


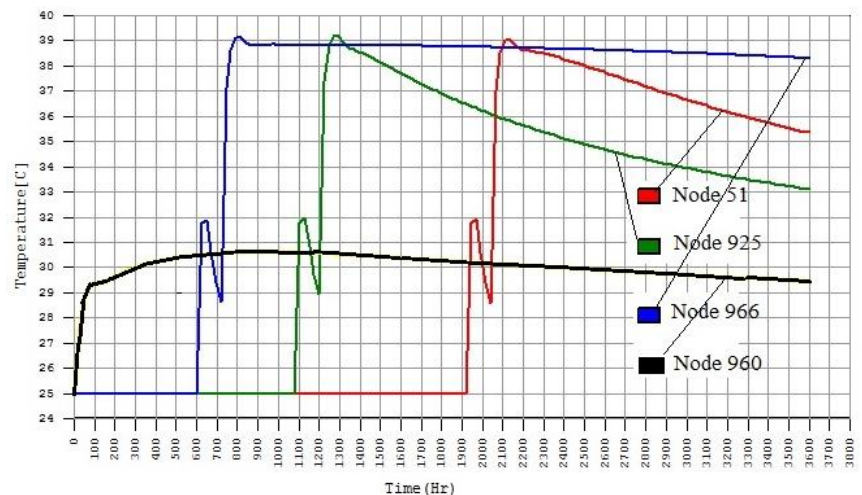

Fig. 6. The graph of temperature distribution and its evolution over time 4 nodes $(960,966,925,51)$

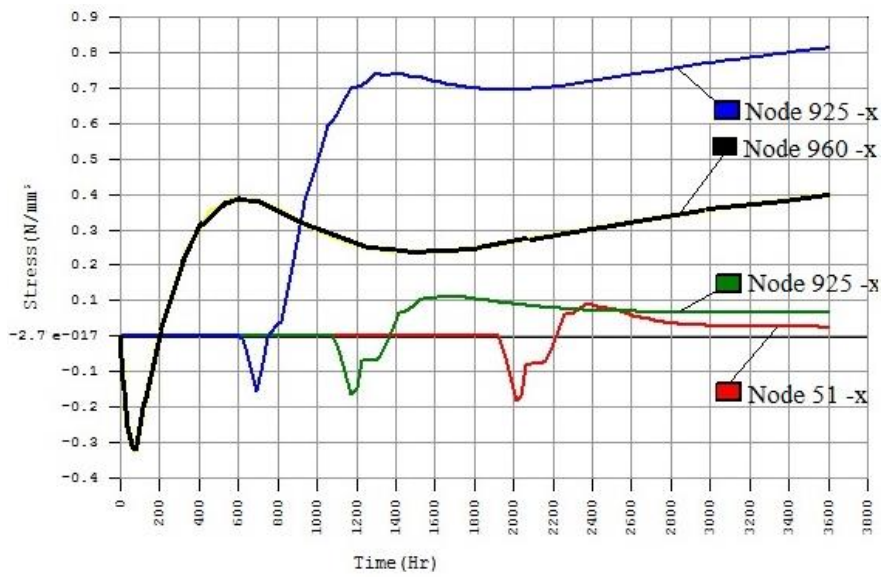

Fig. 7. Main tensile stresses $\sigma_{\mathrm{xx}}$ in 4 nodes $(960,966,925,51) \mathrm{N} / \mathrm{mm}^{2}$

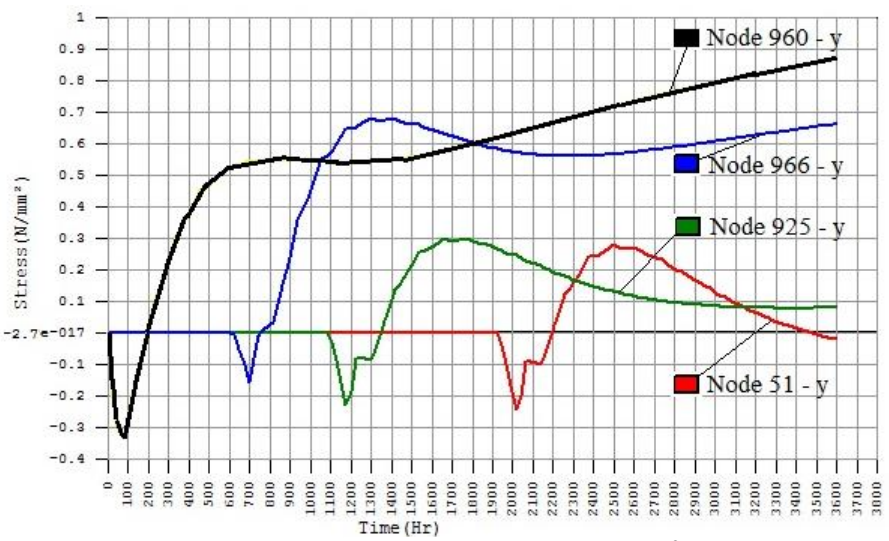

Fig. 8. Main tensile stresses $\sigma_{\mathrm{yy}}$ in 4 nodes $(960,966,925,51) \mathrm{N} / \mathrm{mm}^{2}$

The maximum principal tensile stresses are observed near the bottom face in the zone of the concrete foundation. Closely connecting to the base, horizontal tensile stresses are observed more than in other zone (node 960: $\sigma_{\mathrm{yy}}=0.87 \mathrm{MPa}-$ not causing danger to structures).

Tensile stresses on the lower face of the temperature effects are reduced over time, which is caused by cooling of the central part of the dam. 


\section{Conclusions}

1. With reference to the conditions of cultivation of a concrete dam, which was built in the summer in the northern part of Vietnam, mathematical models of the temperature field of roller-compacted concrete dam during the process of construction are obtained.

2. The models can be used both to evaluate the temperature field of a concrete dam as well as to clarify the parameters of temperature control of roller-compacted concrete dam during the process of construction.

3. With cement consumption $125 \mathrm{~kg} / \mathrm{m}^{3}$, cement maximum heat release $235 \mathrm{~kJ} / \mathrm{kg}$, thickness of the lift placed $1.5 \mathrm{~m}$, temperature of concrete placed $\mathrm{t}_{\mathrm{pl}}=25^{\circ} \mathrm{C}$, by using the Midas Civil 2011, the unsteady temperature problem was solved and the maximum temperature in the dam is determined, which was $\mathrm{T}_{\max }=38.99^{\circ} \mathrm{C}$ after 3600 hours from the beginning of construction. The maximum principal tensile stresses are observed near the bottom face in the base area of the concrete $(0.87 \mathrm{MPa})-$ which reflects the impossibility to form cracks.

\section{References}

1. V. Kuzmanovic, L. Savic, N. Mladenovic, Fac. of Mech. Eng., 43 (2015)

2. K.M. Nemati, Adv. Cons. Tech. U.O.Wash (2016)

3. A. Wondwosen, U. Girum, A. J. o. Eng. and App. Sci., 7 (2014)

4. T.Kurian, P.E. Kavitha, B. Kuriakose, A. J. o. Eng. and App. Sci., 1 (2013)

5. A.M. Lawrence, A finite element model for the prediction of thermal stresses in mass concrete (university of Florida, 2009)

6. B. Li, Z. Wang, Y. Jiang and Z. Zhu, Adv. Mech. Eng., 10 (2018)

7. L.Q. Toan, V.T. Te, V.H. Hung, J. Water Res. and Environ.Sci., 50 (2015)

8. N.A. Aniskin, N. Hoang, Vestnik MGSU., 8 (2014)

9. N.A. Sirii, V.V. Lavrov, Ekaterinburg., 258 (2004)

10. A. Rahimi, J. Noorzaei, Aus. J. B. App. Sci., 12 (2011)

11. N.A. Aniskin, Hydr. Cons., 12 (2005)

12. N. Aniskin, N.T. Chuc, IOP Conf. Ser.: Mater. Sci. Eng., 365, 042083 (2018)

13. MIDAS Information Technology, Heat of Hydration- Analysis Analysis Manual, Version - (2011) 